\title{
MOLECULAR IDENTIFICATION OF FUNGI ISOLATED FROM POSTHARVEST MANGO FRUITS AND EVALUATION OF ESSENTIAL OILS ACTIVITY OF GROWTH INHIBITION
}

\author{
Adilson Ricken Schuelter ${ }^{*}{ }^{\square}$ (iD), Fernando Otaviano da Silva ${ }^{1 凶}$ iD, Rosane dos

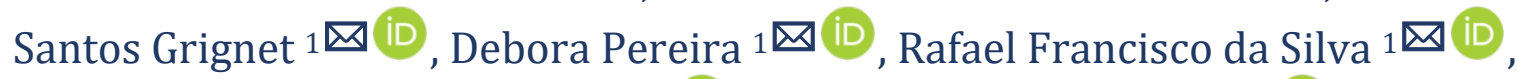

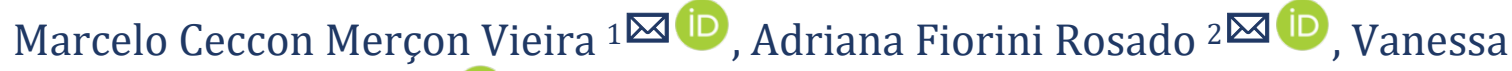 \\ Daneluz Gonçalves ${ }^{3}$ 凹 iD \\ *1 Centro Universitário Dinâmica das Faculdades Cataratas, Foz do Iguaçu (PR), Brazil \\ 2 Federal University of Paraná, Palotina (PR), Brazil \\ 3 State University of Maringá, Umuarama (PR), Brazil
}

DOI: https://doi.org/10.29121/granthaalayah.v9.i3.2021.3782

Article Type: Research Article

Article Citation: Adilson Ricken Schuelter, Fernando Otaviano da Silva, Rosane dos Santos Grignet, Debora Pereira, Rafael Francisco da Silva, Marcelo Ceccon Merçon Vieira, Adriana Fiorini Rosado, and Vanessa Daneluz Gonçalves. (2021). MOLECULAR IDENTIFICATION OF FUNGI ISOLATED FROM POSTHARVEST MANGO FRUITS AND EVALUATION OF ESSENTIAL OILS ACTIVITY OF GROWTH INHIBITION. International Journal of Research -GRANTHAALAYAH, 9(3), 178-189.

https://doi.org/10.29121/granthaa layah.v9.i3.2021.3782

Received Date: 02 March 2021

Accepted Date: 31 March 2021

Keywords:

Mangifera Indica

Fungi Fruits

Sequencing

Essential Oils

Growth Inhibition

\section{ABSTRACT}

This work aimed to perform the molecular identification of fungi mango fruits, in addition to verifying the effect of the essential oils for microbial control. Pericarp segments containing injured and healthy areas of mango fruits were initially disinfested, and then incubated in PDA culture medium at $25^{\circ} \mathrm{C}$. From all isolated material, UDC03, UDC04, UDC09 and UDC12 were preselected, which presented homogeneous cultures. The UDC04 and UDC12 isolates were submitted to the sequencing of the ITS region for presenting mycelial growth both greater and morphologically distinct of fungi from Colletotrichum genus. When BLAST is used in species identification, it was observed that UDC04 and UDC12 belong to Botryosphaeria dothidea and Neofusicoccum parvum, respectively. Regarding the control of UDC04, it was observed that BDA culture medium containing 1.5 to $2 \%$ of lemongrass and eucalyptus oils resulted in complete inhibition. For UDC12, mycelial growth inhibition was detected with the use of $1 \%$ and $1.5 \%$ essential oils of eucalyptus and lemongrass, respectively. The chia essential oil was not effective for the isolates control. Finally, the results reveal the importance of molecular identification of these phytopathogens associated with the establishment of an alternative control of fruits due to problems of contamination with chemical products. 


\section{INTRODUCTION}

Post-harvest losses of vegetables are related to economic losses and the reduction in the organoleptic richness of fruits and vegetables. In Brazil, these losses reach approximately 30\%, being sequential, starting right at the harvest with inadequate handling, going through the processing, classification, packaging and product transportation system, until reaching the consumer (Santos et al., 2020; Henz, 2017).

Among the several factors that directly or indirectly affect post-harvest losses, the diseases caused by phytopathogenic fungi in a quiescent manner stand out, which cause great inconvenience to wholesalers, retailers and, above all, to fruit exporters and importers, such as those from mango fruits (Terao et al., 2013). Anthracnose, a disease caused by fungi of the genus Colletotrichum, is of great importance in the post-harvest of different vegetables, Colletotrichum gloesporioides being the species that causes the greatest economic losses in mangoproducing areas, reaching 100\% losses in areas of tropical and humid climate in the world (Kamle \& Kumar, 2016). In regions with semi-arid climate and/or with low rainfall, where the largest planted area of this fruit is found (Lima et al., 2018), anthracnose is of less importance, concentrating in the rainiest months. In this case, there is a prevalence of diseases such as descending death and pendulum rot, caused by a fungal complex which include the fungi Botryosphaeria dothidea and Neofusicoccum parvum with wide variation of symptoms in the epidermis of the fruits (Batista et al., 2016; Oliveira Costa et al., 2010).

In general, products applied in hoses and in post-harvest to reduce the occurrence of rot have been used aiming to control Colletotrichum gloeosporioides. However, the mistaken identification of the phytopathogen, which is associated with the similarity of the symptoms caused by the infection of Botryosphaeria dothidea and Neofusicoccum parvum in relation to the causal agent of anthracnose can result in ineffective control and promote serious losses, due to the choice of inefficient control methods in the field and in post-harvest (Terao et al., 2013).

The infection of the phytopathogens Botryosphaeria dothidea and Neofusicoccum parvum occurs in the initial flowering phase, when the inflorescence and pedicel are colonized endophytically until reaching the fruit, remaining quiescent until the ripening phase (Saaiman, 1997). As a result of the infection, there is a decrease in the shelf life, as well as a reduction in the size of the fruits, making their commercialization unfeasible (Tavares, 2002).

As a result of the losses caused by these phytopathogens, different control strategies have been suggested, including chemical treatment with pesticides, which are not recommended due to the residues. More recently, the use of the yeast Candida membranifaciens (Terao et al., 2017) has been studied, but there is still no protocol for routine use. Alternatively, essential oils, which are volatile substances, aromatic or odorless, obtained from plant material belonging to the most diverse classes of compounds (Rios, 2016), can present fungistatic and/or fungicide properties, depending on their origin, due to the ability to interact with the cell membrane lipids of microorganisms (Bakkali et al., 2008; Brum et al., 2017).

The composition of essential oils is very variable according to the taxonomic group, the edaphoclimatic conditions and geographical origin (Rios, 2016). Among the different essential oils available on the market, research results show their effect on the control of microorganisms, including fungi that cause economic damage to crops (Carnelossi et al., 2009; Brum et al., 2017; El-Mohamedy, 2017). In addition, recently Elshafie et al. (2018) found that chia essential oil present antibacterial and antifungal activity.

Based on this information, the present study aimed to isolate fungi present in mango fruits that showed characteristics of post-harvest diseases, perform the identification of isolates by analyzing the ITS sequence (internal transcribed spacer) and verify the effect of the application of different sources of oil for the control of these phytopathogens.

\section{MATERIALS AND METHODS}

The present work was carried out in four stages: i) Collection and isolation of fungi in mango fruits; ii) Selection of the most aggressive isolates; iii) Characterization of fungi isolates by DNA analysis; iv) Evaluation of the effect of different sources of essential oils on the inhibition of "in vitro" growth of isolated fungi. 
Molecular Identification of Fungi Isolated from Postharvest Mango Fruits and Evaluation of Essential Oils Activity of Growth Inhibition

\subsection{FUNGAL COLLECTION AND ISOLATION}

Segments of skin tissues of mango fruits with symptoms of disease were sectioned and subjected to disinfestation at the Microbiology Laboratory of the Centro Universitário Dinâmica das Cataratas (UDC), Foz do Iguaçu (PR), Brazil. The disinfestation consisted of 70\% ethanol (30 seconds) and 1\% sodium hypochlorite (1 minute), followed by a triple wash using sterile distilled water. Then, pieces of tissue $\left(0.1 \mathrm{~cm}^{2}\right)$ were transferred to a Petri dish containing potato dextrose agar (PDA) medium and incubated in a greenhouse regulated at $25^{\circ} \mathrm{C}$ for five days (Alfenas et al., 2016; Junior et al., 2009).

Five days after the cultivation of the fungi, $8 \mathrm{~mm}$ diameter mycelium discs were inoculated in the center of a Petri dish containing PDA culture medium. The fungi were incubated in a BOD adjusted to $25{ }^{\circ} \mathrm{C}$ for 8 days of cultivation, with a daily assessment of the growth diameter of the fungi by means of measurement using a digital caliper. The isolates that showed greater development were referred for characterization by DNA analysis.

The experimental design was completely randomized, containing 4 replicates for each isolate. The experimental unit consisted of a Petri dish.

\subsection{MOLECULAR CHARACTERIZATION OF THE ISOLATES}

Prior to the sequencing step the isolated fungi were sent to the Biochemistry and Genetics Laboratory of the Federal University of Paraná / Setor Palotina (LABIOGEN / UFPR) for the DNA extraction and PCR steps.

DNA extraction was performed using the method described by (Kuramae-Izioka, 1997). After DNA purification, the fungi samples were subjected to amplification by the Polymerase Chain Reaction (PCR) of the internal transcript spacer region (ITS) of the ITS1 rDNA, 5.8S-ITS2, according to Mirhendi et al., (2006). The total reaction volume was $25 \mu \mathrm{L}$ containing the genomic DNA, $0.2 \mu \mathrm{M}$ of the forward ITS1 primer (5'-TCCGTAGGTGAACCTGCGG-3') and the reverse ITS4 primer (5'-TCCTCCGCTTATTGATATGC-3') Invitrogen ${ }^{\text {TM }}$, $0.4 \mathrm{mM}$ of the dNTP mix; 4 mM $\mathrm{MgCl}_{2}$; and 1.0 $\mathrm{U}$ of Platinum Taq DNA Polymerase High Fidelity, in the appropriate enzyme buffer (Invitrogen ${ }^{\mathrm{TM}}$ ). The amplification conditions were an initial $5 \mathrm{~min}$ at $94{ }^{\circ} \mathrm{C}$, followed by 25 cycles of 30 seconds at $94{ }^{\circ} \mathrm{C}, 45$ seconds at $55{ }^{\circ} \mathrm{C}$ and 1 minute at $72{ }^{\circ} \mathrm{C}$, with a final extension of 7 minutes at $72{ }^{\circ} \mathrm{C}$, in a Bioneer MyGenie ${ }^{\mathrm{TM}} 96$ thermal cycler.

The amplified fragments were purified using PCR Purification Kit/Ludwig Company. The purified DNA was sequenced using ABI-Prism 3500 Genetic Analyzer (Applied Biosystems) at the LUDWIG/ACTGene Molecular Analysis Company (Alvorada/RS-Brazil). Nucleotide sequences were initially edited using the Bioedit version 7.2.5 software. (Hall, 1999). After editing, processing was carried out, which was based on comparing the DNA sequences obtained with those found on the Nucleotide BLAST (National Center for Biotechnology Information Site). With the information provided by BLAST, the most probable species for the fungal isolates was obtained.

\subsection{EVALUATION OF THE EFFECT OF ESSENTIAL OILS}

Initially, essential oils from lemongrass (Cymbopogon citratus), chia (Salvia hispanica) and eucalyptus (Eucalyptus citriodora) were added in PDA culture medium, previously prepared, with the following concentrations: $0 \%$ (control), 1.6\%, 3.3\%, 5.0\% and 6.4\%. The oils were added to the still melting culture medium, using a magnetic stirrer with heating to homogenize the solution. The mixture was then poured into Petri dishes with a diameter of $90 \mathrm{~mm}$ (Junior et al., 2009). Each treatment received an $8 \mathrm{~mm}$ diameter disk containing mycelia of fungi from pure colonies with an incubation period of 5 days at a temperature of $25^{\circ} \mathrm{C}$. The experimental design was completely randomized with three replications. The experimental unit consisted of a Petri dish containing a mycelium disk obtained after five days of cultivation.

In the second experiment, the effect of eucalyptus and lemongrass essential oils at concentrations of $0 \%, 0.5 \%$, 1.0, 1.5 and $2.0 \%$ on the growth inhibition of Botryosphaeria dothidea (UDC04), Neofusicoccum parvum (UDC12), was evaluated under the same cultivation conditions as in experiment 1. 


\subsection{STATISTICAL ANALYSIS}

The results obtained in this study were subjected to analysis of variance and comparison of means, both at the significance level of $\alpha=0.05$, using the computational applications Statistica (Statsoft., 2004) and SPSS (IBM Corp. Released, 2020).

\section{RESULTS AND DISCUSSIONS}

\subsection{ISOLATION AND MOLECULAR CHARACTERIZATION}

Initially, fifteen samples of fruits with characteristic of post-harvest diseases were used to carry out the disinfestation process. As the treatment with 30 seconds of alcohol (70\%) and 1 minute of sodium hypochlorite (1\%) was efficient for the elimination of superficial microorganisms from the injured tissue, it was carried out twice to obtain pure colonies. From the total of isolated material, four samples were selected that showed rapid and homogeneous growth, called UDC03, UDC04, UDC09 and UDC12, which are illustrated in Figure 1.

By assessing the growth diameter of the isolates grown for 8 days in PDA culture medium, using mycelium discs previously grown in the same composition medium, it was found that the UDC12 and UDC04 isolates took four and five days respectively to occupy the Petri dish area (Figure 2).

With the results of the analysis of variance of repeated measures, the absence of sphericity was initially detected by the Mauchly test $(\mathrm{W}=0.002$ and $\mathrm{p}<0.01)$, and the data were corrected by Greenhouse-Geisser $(\varepsilon=0.389)$. By interpreting the results of the analysis of variance, the following significance was detected for the effects of time $[F(2.724 ; 32.694)=2457.431$ and $p<0.01]$, of the interaction Isolated $x$ Time $[F(8.173 ; 32.694)=77.179$ and $p<0.01]$ and from the Isolate $(\mathrm{F}=4101.933$ and $\mathrm{p}<0.01)$, indicating that UDC03, UDC04, UDC09 and UDC12 present differential mycelial growth in relation to the incubation time.

By interpreting the estimated marginal means (Figure 2) and comparing them using the Pairwise method (Bonferroni correction), it was found that the UDC12 and UDC04 isolates, which showed greater mycelial growth compared to UDC03 and UDC09, differed statistically from the second on the fourth day of incubation ( $<<0.01)$, with UDC12 having the highest averages.

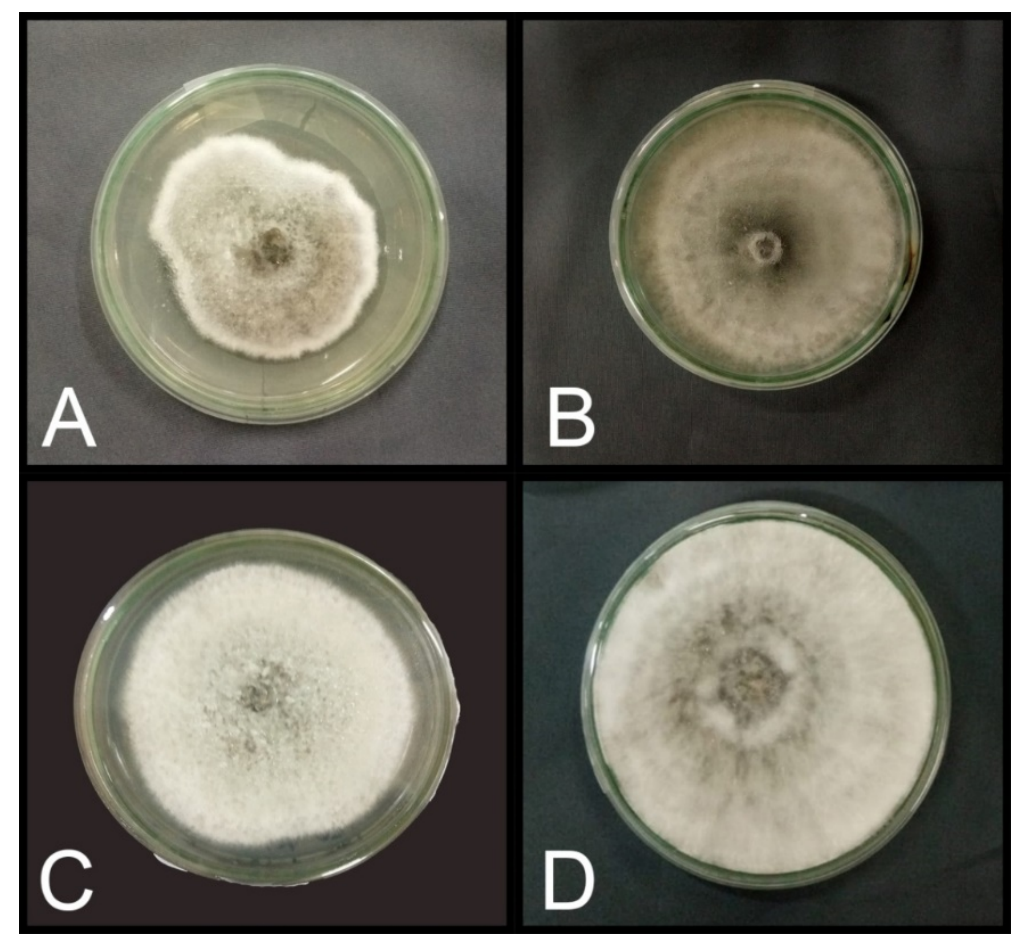

Figure 1: Isolates of fungi obtained from fruits with lesions, where: UDC09 (A), UDC03 (B), UDC04 (C) e UDC12 (D). 


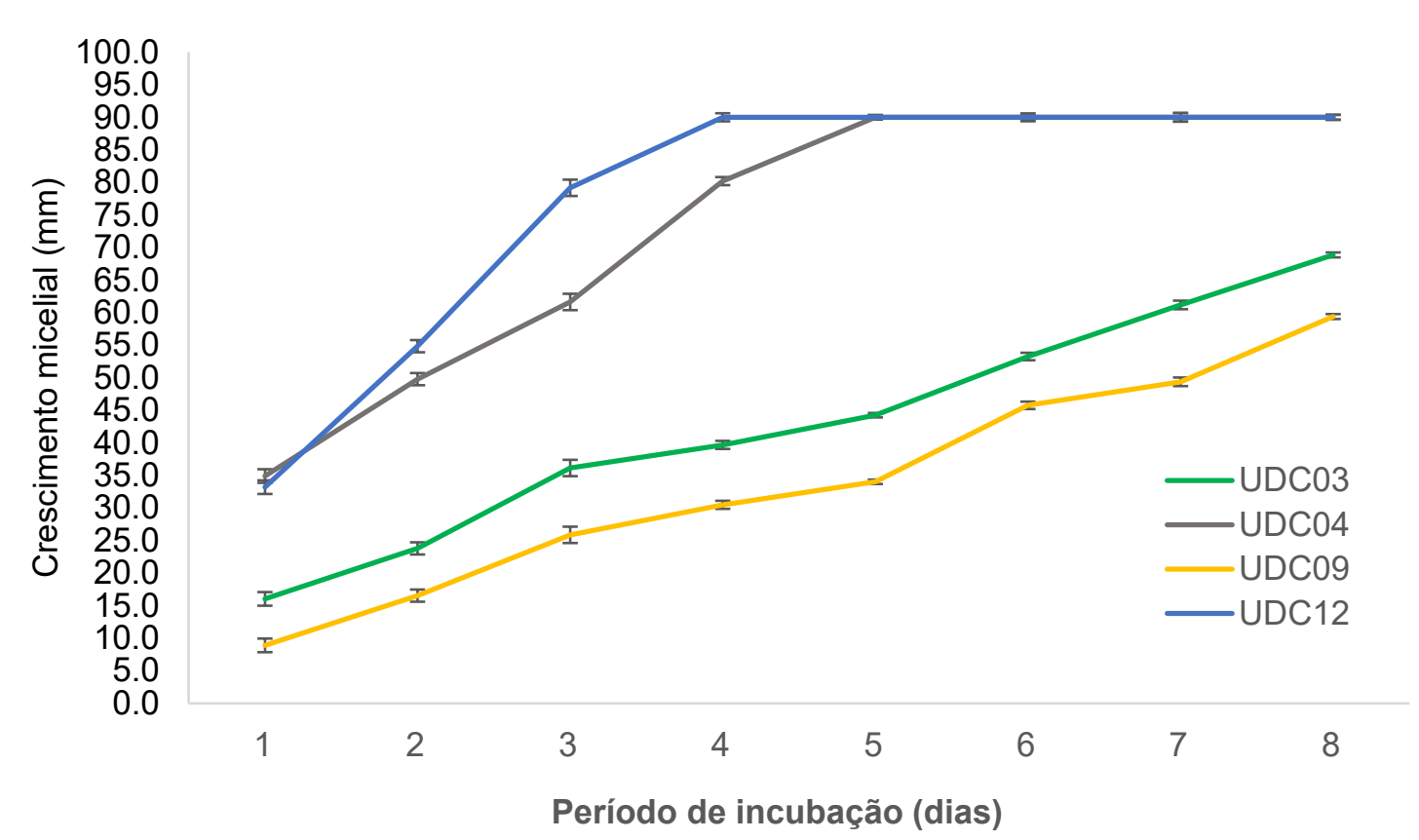

Figure 2: Growth curves obtained from the mycelial disc of the isolates as a function of the period of incubation in PDA culture medium at $25^{\circ} \mathrm{C}$.

By evaluating the culture aspect of the isolates, similarities were found with Colletrotrichum isolates, however, by microscopic analysis, it was concluded that the UDC04 and UDC12 isolates did not belong to this genus. Thus, DNA from the UDC04 and UDC12 isolates, which showed greater growth in PDA, were extracted with good quality, and the PCR methodology applied with the primers designed by Mirhendi et al. (2006) generated fragments of approximately 600 base pairs. With the determination of the sequences of the amplified fragments and their respective editions, and submitting the data to the analysis by BLAST, it was found that the isolates UDC04 and UDC12 were, respectively, Neofusicoccum parvum and Botryosphaeria dothidea.

According to Ploetz and Freeman (2009), fungus Neofusicoccum parvum, in addition to causing soft and/or peduncular rot, can cause descending death and burning of inflorescence, and young fruits can mummify, even when attached to the plant, or fall early. This phytopathogen also develops symptoms of spots on fruits, initially appearing a small lesion, sometimes soaked, that progresses to a light brown spot with poorly defined edges. These symptoms are commonly confused, by producers, with those of anthracnose, caused by the fungus Colletotrichum spp (Terao et al., 2013).

Botryosphaeria dothidea, in addition to not needing injuries to cause infection, the lesions on the fruit become visible between six and eight weeks before harvest, however, the infection can occur at the beginning of the vegetative cycle, remaining latent, without manifesting symptoms until the beginning of maturation, with mummified fruits and premature fall, similar in some aspects to N. parvum and Colletotrichum spp, being difficult to identify in fruits based on morphological characters (Boneti, 1999; Berton et al., 2006; Dias, 2014).

Table 1: Molecular identification of UDC04 and UDC12 isolates by comparing the sequences obtained from the amplification of the genomic region of the internal transcribed spacer (ITS) of the rDNA using BLAST in the NCBI

\begin{tabular}{|c|c|c|c|c|c|c|}
\hline \multirow{2}{*}{ Isolate } & \multicolumn{6}{|c|}{ Analysis by BLAST/NCBI } \\
\cline { 2 - 7 } & Primer F & $\begin{array}{c}\text { Similar } \\
(\%)\end{array}$ & $\begin{array}{c}\text { Sequence } \\
\text { (nt) }\end{array}$ & Primer R & $\begin{array}{c}\text { Similar } \\
(\%)\end{array}$ & $\begin{array}{c}\text { Sequence } \\
\text { (nt) }\end{array}$ \\
\hline UDC04 & Botryosphaeria dothidea & 98 & 564 & Botryosphaeria dothidea & $99 \%$ & 441 \\
\hline UDC12 & Neofusicoccum parvum & 98 & 870 & $\begin{array}{c}\text { Neofusicoccum } \\
\text { kwambonambiense }\end{array}$ & $100 \%$ & 551 \\
\hline
\end{tabular}




\subsection{EFFECT OF ESSENCIAL OILS ON THE GROWTH CONTROLO OF ISOLATES}

In order to verify the effect of essential oils of chia, lemongrass and eucalyptus on the growth control of UDC04 (Botryosphaeria dothidea) and UDC12 (Neofusicoccum parvum) isolates, fungi samples were cultivated in BDA culture medium containing different essentials oil concentrations for a period of 5 days.

By analyzing the variance at the significance level $\alpha=0.05$, performed for the response of mycelium diameter of the UDC04 isolate (Figure 3a), a statistical difference was detected for the treatments that contained different concentrations of chia oil $(0 ; 1.6 ; 3.2 ; 5.0$ and 6.4\%), in the readings taken on days 1,2 and 3 (all with pvalue<0.0001).

With the comparison of means (Table 2), it was noticed that the treatment with $3.2 \%$ chia oil (Tch-3.2) promoted the smallest growth $(16.27 \mathrm{~mm})$ of the fungus UDC04 on the first day of cultivation. However, on the second day of cultivation, the growth inhibition potential observed with the concentration of $3.2 \%$ was statistically equal to that obtained with the concentrations of 5.0\% (Tch-5.0) and 6.4\% (Tch-6.4). The fungal growth inhibiting effect was reduced from the third day of cultivation. On the third day of cultivation, the results obtained with treatments containing $5.0 \%(74.69 \mathrm{~mm})$ and $6.4 \%(65.57 \mathrm{~mm})$ of chia essential oil were statistically similar to the control treatment Tch-0 $(75.10 \mathrm{~mm})$. From the fourth day of cultivation, the UDC04 fungus grew across the plate diameter $(90 \mathrm{~mm})$ in all treatments, that is, the treatments with essential oil of chia in the working concentrations did not promote inhibition of the growth of the UDC04 fungus satisfactorily, as shown in Figure 3a.
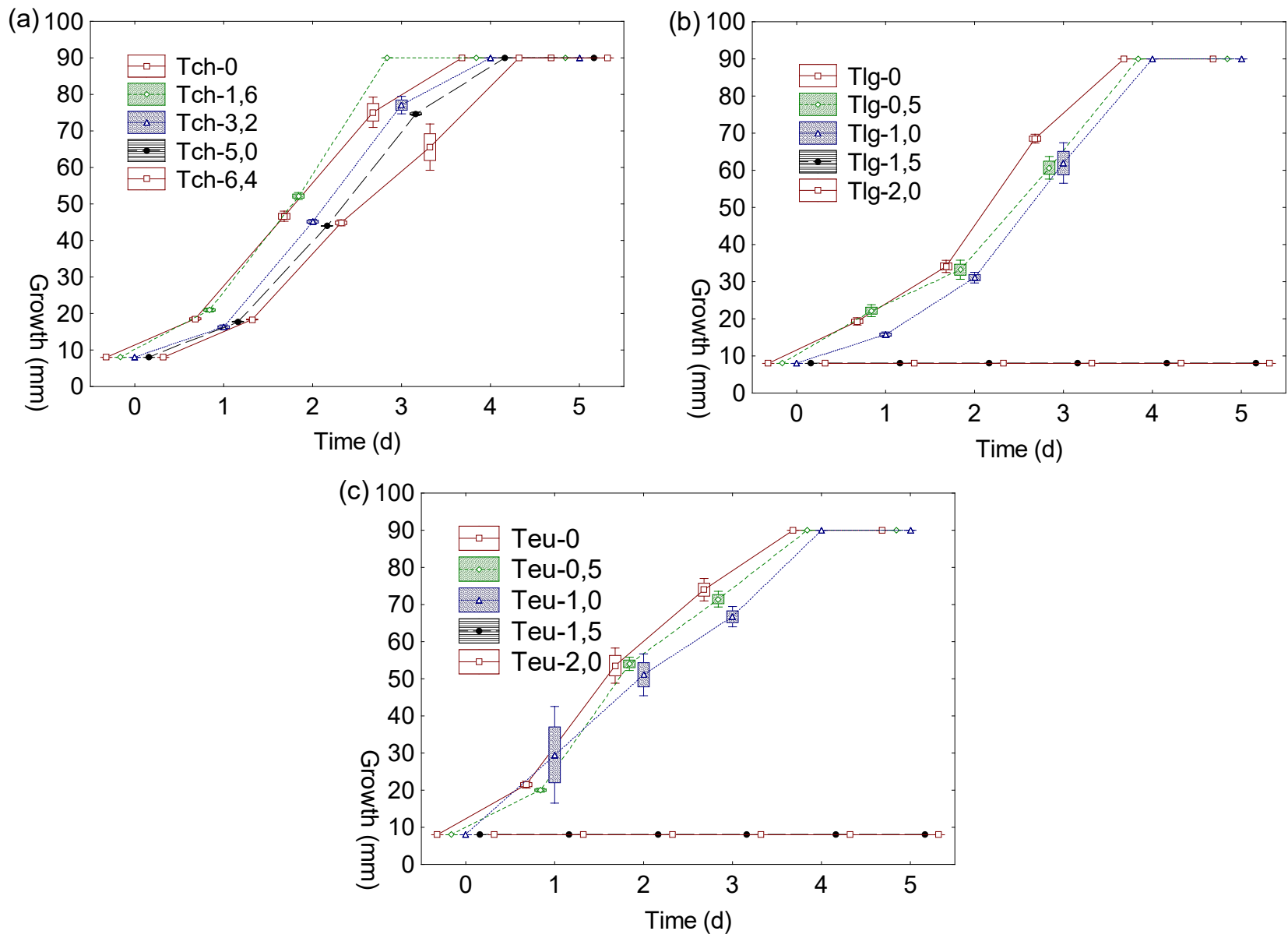

Figure 3: Growth evolution of the UDC04 fungus grown for 5 days in (a) chia; (b) lemon grass; and (c) eucalyptus oil. Where: Central point $=$ Average; Box $=$ Mean \pm Standard Error; Bar $=$ Mean \pm Standard Deviation. Tch-0: treatment "T"; Chia "ch" and "0" concentration in percentage of chia essential oil. Tlg-0: treatment "T"; Lemon grass "lg" and " 0 " concentration in percentage of lemon grass essential oil. Teu-0: treatment "T"; Eucalyptus "eu" and "0" concentration in percentage of eucalyptus essential oil. 
Table 2: Comparison of means by the Tukey test $(\alpha=0.05)$ for the mycelial growth evolution of the UDC04 isolate in PDA culture medium supplemented with different concentrations of essential oils of chia

\begin{tabular}{|c|c|c|c|}
\hline \multirow{2}{*}{ Treatment } & \multicolumn{3}{|c|}{ Growth Evolution (mm) } \\
\cline { 2 - 4 } & Day 1 & Day 2 & Day 3 \\
\hline Tch-0 & $18,56^{\mathrm{b}}$ & $46,63^{\mathrm{b}}$ & $75,10^{\mathrm{a}, \mathrm{b}}$ \\
\hline Tch-1,6 $^{\mathrm{b}}$ & $20,96^{\mathrm{c}}$ & $52,17^{\mathrm{c}}$ & $90,00^{\mathrm{c}}$ \\
\hline Tch-3,2 $^{1}$ & $16,27^{\mathrm{a}}$ & $45,13^{\mathrm{a}, \mathrm{b}}$ & $77,07^{\mathrm{b}}$ \\
\hline Tch-5,0 & $17,78^{\mathrm{b}}$ & $43,97^{\mathrm{a}}$ & $74,69^{\mathrm{a}, \mathrm{b}}$ \\
\hline Tch-6,4 & $18,36^{\mathrm{b}}$ & $44,84^{\mathrm{a}, \mathrm{b}}$ & $65,57^{\mathrm{a}}$ \\
\hline
\end{tabular}

Where: ${ }^{1}$ Tch-3,2: treatment "T"; Chia "ch" and "3.2" concentration in percentage of chia essential oil. Superscript letter after the growth mean represents statistical difference by the Tukey test $(\alpha=0.05)$. As of the 4 th day of cultivation, the Tukey test was not performed due to failure to meet the assumptions of ANOVA.

Plants of the Lamiaceae family such as Origanum vulgare L., Thymus vulgaris L., Salvia sclarea L. and Lavandula angustifolia have been used for many years due to their medicinal properties (Bakkali et al., 2008). Recently, in a study by Elshafie et al. (2018), chia essential oil presented antibacterial and fungal activity, being mainly constituted by sesquiterpenes, with caryophyllenes as the main constituents. However, due to the results obtained in this research, chia oil did not present potential for use in the control of Botryosphaeria dothidea. Similar results were obtained by Puškárová et al. (2017) with Salvia officinalis, having concluded that essential oil has no potential for microbial control.

As the complete inhibition of the mycelial growth of the UDC0 4 isolate was verified with the use of $1.6 \%$ to $6.4 \%$ of lemon grass and eucalyptus essential oils, the isolate was evaluated in lower concentrations $(0 ; 0.05 ; 1.0 ; 1.5$ and $2.0 \%$ ) of essential oils of lemon grass and eucalyptus (Figures $3 b$ and $3 c$, respectively). By the results obtained from the analysis of variance for the mycelium diameter, a significant difference ( $p$-value<0.0001) was detected between the growth responses of the fungus UDC04, 5 days cultivation.

By comparing the mycelium diameter for the different treatments (Tables 3 and 4 and Figures 3b and 3c), it was found that concentrations of $1.5 \%$ and $2.0 \%$ of essential oil of lemon grass (Tlg-1.5 and Tlg-2.0) and eucalyptus (Teu1.5 and Teu-2.0), promote $100 \%$ inhibition of the mycelial growth of the fungus UDC04 during the 5 days of cultivation. On the other hand, the use of $1.0 \%$ of these essential oils resulted in growth suppression, but at the end of the incubation period it did not differ from treatments with lower concentration. These results reveal that these essential oils have an effect on the control of mycelial growth of Botryosphaeria dothidea isolate, and the use of $1.5 \%$ of essential oil is enough to guarantee the growth inhibition of this phytopathogen.

Table 3: Comparison of means by the Tukey test $(\alpha=0.05)$ for the evolution of mycelial growth of the UDC04 isolate in PDA culture medium supplemented with different concentrations of essential oils of lemongrass

\begin{tabular}{|c|r|r|c|}
\hline \multirow{2}{*}{ Treatment } & \multicolumn{3}{|c|}{ Growth evolution (mm) } \\
\cline { 2 - 4 } & Day 1 & Day 2 & Day 3 \\
\hline Tlg-0 & $19,31^{\mathrm{c}}$ & $34,11^{\mathrm{b}}$ & $68,52^{\mathrm{c}}$ \\
\hline Tlg-0,5 & $22,20^{\mathrm{d}}$ & $33,22^{\mathrm{b}}$ & $60,68^{\mathrm{b}}$ \\
\hline Tlg-1,0 & $15,75^{\mathrm{b}}$ & $31,10^{\mathrm{b}}$ & $61,96^{\mathrm{b}, \mathrm{c}}$ \\
\hline Tlg-1,5 & $8,00^{\mathrm{a}}$ & $8,00^{\mathrm{a}}$ & $8,00^{\mathrm{a}}$ \\
\hline Tlg-2,0 & $8,00^{\mathrm{a}}$ & $8,00^{\mathrm{a}}$ & $8,00^{\mathrm{a}}$ \\
\hline
\end{tabular}

Where: ${ }^{1}$ Tlg-1.5: "T" treatment; Lemon grass "lg" and "1.5" concentration in percentage of lemon grass essential oil. Superscript letters after the growth mean represent statistical difference by the Tukey test $(\alpha=0.05)$. As of the 4 th day of cultivation, the Tukey test was not performed due to failure to meet the assumptions of ANOVA. 
Table 4: Comparison of means by the Tukey test $(\alpha=0.05)$ for the evolution of mycelial growth of the UDC04 isolate in PDA culture medium supplemented with different concentrations of essential eucalyptus oils

\begin{tabular}{|c|c|r|c|}
\hline \multirow{2}{*}{ Treatment } & \multicolumn{3}{|c|}{ Growth Evolution (mm) } \\
\cline { 2 - 4 } & Day 1 & Day 2 & Day 3 \\
\hline Teu-0 & $21,49^{\mathrm{a}, \mathrm{b}}$ & $53,55^{\mathrm{b}}$ & $73,99^{\mathrm{c}}$ \\
\hline Teu-0,5 & $20,00^{\mathrm{a}, \mathrm{b}}$ & $54,02^{\mathrm{b}}$ & $71,44^{\mathrm{b}, \mathrm{c}}$ \\
\hline Teu-1,0 & $29,53^{\mathrm{b}}$ & $51,08^{\mathrm{b}}$ & $66,72^{\mathrm{b}}$ \\
\hline Teu-1,5 & $8,00^{\mathrm{a}}$ & $8,00^{\mathrm{a}}$ & $8,00^{\mathrm{a}}$ \\
\hline Teu- $2,0^{1}$ & $8,00^{\mathrm{a}}$ & $8,00^{\mathrm{a}}$ & $8,00^{\mathrm{a}}$ \\
\hline
\end{tabular}

Where: ${ }^{1}$ Teu-2.0: treatment "T"; Eucalyptus "eu" and "2.0" concentration in percentage of eucalyptus essential oil. Superscript letters after the growth mean represent statistical difference by the Tukey test $(\alpha=0.05)$. As of the 4 th day of cultivation, the Tukey test was not performed due to failure to meet the assumptions of ANOVA.

Similar to the results obtained with the Botryosphaeria dothidea isolate, treatments with chia oil were also not efficient in inhibiting the growth of Neofusicoccum parvum (UDC12), even at high concentrations employed, 1.6 to $6.4 \%$ (Figure 4a). On the other hand, when using lemongrass and eucalyptus oils on these same concentrations in the culture medium, a complete inhibition of the mycelial growth of UDC12 was observed, that is, it remained with $8 \mathrm{~mm}$ in diameter during the entire period of the experiment. Thus, the growth of the UDC12 isolate was evaluated in lower concentrations (0; 0.05; 1.0; 1.5 and 2.0\%) of essential oils of lemon grass and eucalyptus (Figures $4 \mathrm{~b}$ and 4c).
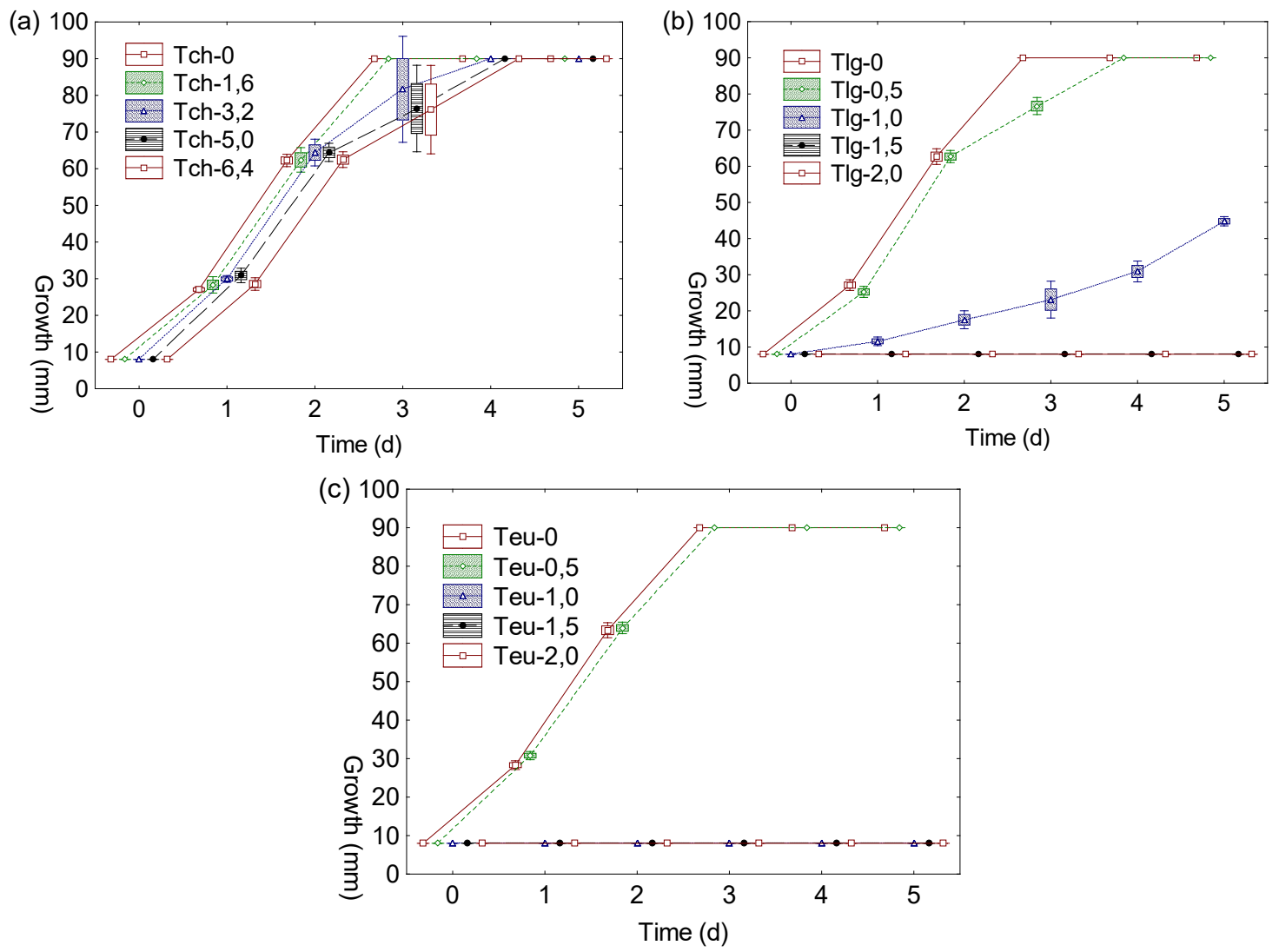

Figure 4: Growth evolution of the UDC12 fungus grown for 5 days in (a) chia; (b) lemongrass; and (c) eucalyptus oil. Where: Central point $=$ Average; Box $=$ Mean \pm Standard Error; Bar $=$ Mean \pm Standard Deviation. Tch-0: treatment "T"; Chia "ch" and "0" concentration in percentage of chia essential oil. Tlg-0: treatment "T"; Lemon grass "lg" and " 0 " concentration in percentage of lemon grass essential oil. Teu-0: treatment "T"; Eucalyptus "eu" and "0" concentration in percentage of eucalyptus essential oil. 
By reducing the concentrations of lemongrass and eucalyptus oil in the culture medium, it was detected by ANOVA $(\alpha=0.05)$ that the isolated Neofusicoccum parvum (UDC12) presented different mycelial growth responses in relation to the treatments ( $\mathrm{p}$-value<0.0001). During the entire incubation period of the UDC12 fungus (Table 5), there was $100 \%$ growth inhibition with the use of $1.5 \%$ (Tlg-1.5) and $2.0 \%$ (Tlg-2.0) of lemongrass essential oil (Figure 4b). The use of 1.0\% (Teu-1.0) of eucalyptus essential oil was sufficient for the total inhibition of mycelial growth, being statistically equal to that obtained with concentrations of $1.5 \%$ (Teu-1.5) and 2.0\% (Teu-2.0) of the same oil (Table 6 and Figure 4c).

Table 5: Comparison of means by the Tukey test $(\alpha=0.05)$ for the evolution of mycelial growth of the UDC12 isolate in PDA culture medium supplemented with different concentrations of lemongrass essential oils

\begin{tabular}{|c|c|c|c|c|c|}
\hline \multirow{2}{*}{ Treatment } & \multicolumn{5}{|c|}{ Growth evolution (mm) } \\
\cline { 2 - 6 } & Day 1 & Day 2 & Day 3 & Day 4 & Day 5 \\
\hline Tlg-0 & $27,14^{\mathrm{c}}$ & $62,67^{\mathrm{c}}$ & $90,00^{\mathrm{d}}$ & $90,00^{\mathrm{c}}$ & $90,00^{\mathrm{c}}$ \\
\hline Tlg-0,5 & $25,2^{\mathrm{c}}$ & $62,69^{\mathrm{c}}$ & $76,65^{\mathrm{c}}$ & $90,00^{\mathrm{c}}$ & $90,00^{\mathrm{c}}$ \\
\hline Tlg-1,0 & $11,58^{\mathrm{b}}$ & $17,54^{\mathrm{b}}$ & $23,2^{\mathrm{b}}$ & $30,90^{\mathrm{b}}$ & $44,78^{\mathrm{b}}$ \\
\hline Tlg-1,5 $^{1}$ & $8,00^{\mathrm{a}}$ & $8,00^{\mathrm{a}}$ & $8,00^{\mathrm{a}}$ & $8,00^{\mathrm{a}}$ & $8,00^{\mathrm{a}}$ \\
\hline Tlg-2,0 & $8,00^{\mathrm{a}}$ & $8,00^{\mathrm{a}}$ & $8,00^{\mathrm{a}}$ & $8,00^{\mathrm{a}}$ & $8,00^{\mathrm{a}}$ \\
\hline
\end{tabular}

Where: ${ }^{1}$ Tlg-1.5: "T" treatment; Lemongrass "lg" and "1.5" concentration in percentage of lemongrass essential oil. Superscript letters after the growth mean represent statistical difference by the Tukey test $(\alpha=0.05)$.

Table 6: Comparison of means by the Tukey test $(\alpha=0.05)$ for the evolution of mycelial growth of the UDC12 isolate in PDA culture medium supplemented with different concentrations of essential eucalyptus oils

\begin{tabular}{|c|r|c|}
\hline \multirow{2}{*}{ Treatment } & Growth evolution (mm) \\
\cline { 2 - 3 } & Day 1 & Day 2 \\
\hline Teu-0 & $28,30^{\mathrm{b}}$ & $63,36^{\mathrm{b}}$ \\
\hline Teu-0,5 & $30,78^{\mathrm{c}}$ & $63,96^{\mathrm{b}}$ \\
\hline Teu-1,0 & $8,00^{\mathrm{a}}$ & $8,00^{\mathrm{a}}$ \\
\hline Teu-1,5 & $8,00^{\mathrm{a}}$ & $8,00^{\mathrm{a}}$ \\
\hline Teu-2,0 & $8,00^{\mathrm{a}}$ & $8,00^{\mathrm{a}}$ \\
\hline
\end{tabular}

Where: ${ }^{1}$ Teu-2.0: treatment "T"; Eucalyptus "eu" and "2.0" concentration in percentage of eucalyptus essential oil. Superscript letters after the growth mean represent statistical difference by the Tukey test $(\alpha=0.05)$. From the 3rd day of cultivation, the Tukey test was not performed due to failure to meet the assumptions of ANOVA.

According to Martinazzo et al. (2019), the different essential oils are found in different parts of the plant, and their composition can be modified by different factors of environment and cultivation. In this context, essential oils from different plant species have been used for microbial control, including phytopathogens. In a study by Sarkhosh et al. (2018), essential oils from different plant species showed a differential capacity to control the mycelial growth of phytopathogens. For the Botryosphaeria isolate, derived from avocado fruit, the control was effective with the use of essential oil from species of the Lamiaceae family, Satureja khuzistanica and Thymus daenensis. On the other hand, Eucalyptus globulus oil used in the same concentrations did not provide complete inhibition of mycelial growth.

The essential oils of Eucalyptus spp. have been widely used due to their bioactive properties, including their potential as antimicrobial control agent. In the present study, it was found that E. citriodora essential oil was efficient in controlling the mycelial growth of Botryosphaeria dothidea (UDC04) and Neofusicoccum parvum (UDC12) with the use of $1.5 \%$ and $1.0 \%$ in the PDA culture. According to results from the literature, essential oil of this species has a predominance of citronella (Costa et al., 2015; Lee et al., 2008), but there is a wide diversity of substances with antimicrobial activity such as citronellol and geraniol (Pereira et al., 2015).

In a study performed by Zhang et al. (2018), tests to evaluate natural compounds with antifungal action revealed that cuminaldehyde, $\beta$-citronelol, nerol, geraniol, citral and $\alpha$-terpineol exhibited a strong antifungal effect against Botryosphaeria dothidea. In this context, lemongrass essential oil is rich in these compounds (Vyshali et al., 2015; Andrade et al., 2009), which may justify its effectiveness in controlling the UDC04 isolate. However, it should be noted that for the complete inhibition of mycelial growth of Botryosphaeria dothidea, it was necessary to use a PDA 
culture medium with $1.5 \%$ lemongrass essential oil, which is superior to the results obtained in researches with other phytopathogens (Oliveira et al., 2020; Brum et al., 2017; Santos et al., 2013).

The chemical composition of substances from cellular metabolism, especially those from secondary metabolism, varies widely. According to Majewska et al. (2019), genetic-environmental factors, crop management, harvesting and essential oils extracting methods have a direct or indirect influence on the oil obtained, especially for the lemongrass oil. Thus, it should be noted that the efficiency of antimicrobial control may be associated with the batch of oil extracted.

Regarding the isolate of Neofusicoccum parvum (UDC12), which showed inhibition of mycelial growth for the concentrations used of essential oils of lemongrass and eucalyptus, it should be noted that these results are innovative, with little scientific information proving control alternative of this phytopathogen. In this context, Faiza et al. (2018) found that the use of essential oil of Origanum glandulosum, an endemic species from North Africa which belongs to the Lamiaceae family, with a very different composition in relation to the oils of lemongrass and eucalyptus, showed growth control of Neofusicossum parvum.

Thus, the present research result confirms the importance of studies that perform the taxonomic identification of phytopathogenic agents, which are considered of secondary importance, but which has increased in importance due to the increase in the losses caused. In addition, the establishment of control methods, preferably alternative ones, such as the use of essential oils, are of great importance, since these natural products are highly safe for humans and the environment. For these reasons, and considering the results obtained with Botryosphaeria dothidea (UDC04) and Neofusicoccum parvum (UDC12), the use of essential oils of lemongrass and eucalyptus is recommended.

\section{CONCLUSIONS AND RECOMMENDATIONS}

The isolation and growth of phytopathogens in PDA culture medium allowed the selection of four isolates, with UDC0 4 and UDC12 showing rapid growth.

By analyzing the amplified sequence of the ITS region, it was possible to identify the UDC04 and UDC12 isolates, with greater growth capacity in PDA, as Botryosphaeria dothidea and Neofusicoccum parvum, respectively.

The use of lemongrass essential oils (Cymbopogon citratus) and eucalyptus (Eucalyptus citriodora) was effective in controlling the mycelial growth of UDC04 and UDC12 isolates. Essential oil of chia (Salvia hispanica) was not effective for the control of these phytopathogens.

\section{SOURCES OF FUNDING}

This research received no specific grant from any funding agency in the public, commercial, or not-for-profit sectors.

\section{CONFLICT OF INTEREST}

The author have declared that no competing interests exist.

\section{ACKNOWLEDGMENT}

We would like to thank the UDC/Foz and UFPR/Palotina for allowing the access of Labs where the molecular characterization and antimicrobial activity experiments were performed.

\section{REFERENCES}

[1] Alfenas, A. C., et al, Isolamento de fungos fitopatogênicos. Métodos em fitopatologia. Viçosa: UFV; 2016, 55-92.

[2] Andrade, E. H. A., Zoghbi, M. das G. B., and Lima, M. da P. Chemical composition of the essential oils of Cymbopogon citratus (DC.) Stapf cultivated in North of Brazil. Journal of essential oil bearing plants, Vol. 12, No. 1, Mar. 2009, 41-45. 
Molecular Identification of Fungi Isolated from Postharvest Mango Fruits and Evaluation of Essential Oils Activity of Growth Inhibition

[3] Bakkali, F., et al. Biological effects of essential oils-a review. Food and chemical toxicology, Vol. 46, No. 2, Feb. 2008, 446-475.

[4] Batista, D. D. C., et al. Doenças da mangueira. Informe Agropecuário, Vol. 37, No. 290, Nov. 2016, 82-91.

[5] Berton, O., et al., Doenças fúngicas dos ramos: podridão-branca - Botryosphaeria dothidea In: EPAGRI. A cultura da macieira. Florianópolis: EPAGRI, 2006, 567-571.

[6] Boneti, J. I. S. Doenças da macieira (Malus domestica Bork). In: Boneti JIS, Ribeiro LG, Katsurayama Y (Eds.) Manual de identificação de doenças e pragas da macieira. Florianópolis: EPAGRI, 1999, 13-95.

[7] Brum, R. B. C. S., et al. Atividade antifúngica de óleos essenciais sobre fungos fitopatogênicos. Magistra, Vol. 26, No. 3, Jul/Set. 2014, 361-371.

[8] Carnelossi, P. R., et al. Óleos essenciais no controle pós-colheita de Colletotrichum gloeosporioides em mamão. Revista Brasileira de Plantas Medicinais, Vol. 11, No. 4, Abr. 2009, 399-406.

[9] Costa, A. V., et al. Chemical composition of essential oil from Eucalyptus citriodora leaves and insecticidal activity against Myzus persicae and Frankliniella schultzei. Journal of Essential Oil Bearing Plants, Vol. 18, No. 2, Jun. 2015, 374-381.

[10] Dias, J. A. Botryosphaeria dothidea. Defesa vegetal.net, 2014. Retrieved from: http://www.defesavegetal.net/botsdo.Acesso 10 agot. 2018.

[11] Oliveira, F. da S. de, et al. Evaluation of the antifungal potential of Cymbopogon citratus essential oil in the control of the fungus Aspergillus brasiliensis. Research, Society and Development, Vol. 9, No. 7, June 2020, 691974697.

[12] Oliveira Costa, V. S. de, et al. Species of Botryosphaeriaceae associated on mango in Brazil. European Journal of Plant Pathology, Vol. 127, No. 4, May 2010, 509-519.

[13] El-Mohamedy, R. S. R. Plant essential Oils for controlling Plant pathogenic Fungi. In: Volatiles and Food Security. Singapore: Springer, 2017, 171-198.

[14] Elshafie, H. S. et al. Chemical composition and antimicrobial activity of chia (Salvia hispanica L.) essential oil. European Food Research and Technology, Vol. 244, No. 9, Sept. 2018, 1675-1682.

[15] Faiza, A., Aouich, A., and Redha, B. The Chemical Composition and the Antifungal Activity of the Essential Oil of Origanum glandulosum against Neofusicoccum parvum. Jordan Journal of Biological Sciences, Vol. 11, No. 2, June 2018, 117-121.

[16] Hall T.A. BioEdit: a user-friendly biological sequence alignment editor and analysis program for Windows 95 / 98 / NT. Nucleic Acids Symposium Series, Vol 41, 1999, 95-98.

[17] Henz, G. P. Postharvest losses of perishables in Brazil: what do we know so far? Horticultura Brasileira, Vol. 35, No. 1, Jan/ Mar. 2017, 6-13.

[18] IBM Corp. Released. IBM SPSS Statistics for Windows. Version 27.0 [Programa de computador]. Armonk, Nova York: IBM Corp, 2020.

[19] Junior, I. T. S., Sales, N. L., and Martins, E. R. Efeito fungitóxico de óleos essenciais sobre Colletotrichum gloeosporioides, isolado do maracujazeiro amarelo. Biotemas, Vol. 22, No. 3, Mar. 2009, 77-83.

[20] Kamle, M., and Kumar, P. Colletotrichum gloeosporioides: Pathogen of Anthracnose Disease in Mango (Mangifera indica L.). In: Kumar, P., et al. (eds) Current Trends in Plant Disease Diagnostics and Management Practices. Springer, Cham, 2016, 207-219.

[21] Kuramae-Izioka, E. E. A rapid, easy and high yield protocol for total genomic DNA isolation of Colletotrichum gloesporioides and Fusarium oxysporum. Revista Unimar, Marília, Vol. 19, No. 3, Aug. 1997, 683-689.

[22] Lee, Y. S., et al. Antifungal activity of Myrtaceae essential oils and their components against three phytopathogenic fungi. Flavour and Fragrance Journal, Vol. 23, No. 1, Jan. 2008, 23-28.

[23] Lima, J. R. F. de, et al. Análise do mercado de manga produzida no Vale do São Francisco: cenário atual e perspectivas para o curto prazo. In Embrapa Semiárido-Artigo em anais de congresso (ed) Congresso Da Sociedade Brasileira de Economia, Administração e Sociologia Rural Do Regional Nordeste, Juazeiro: UNIVASF: SOBER-NE, Nov. 2018, 1-19.

[24] Majewska, E., et al. Lemongrass (Cymbopogon citratus) essential oil: extraction, composition, bioactivity and uses for food preservation-a review. Polish Journal of Food and Nutrition Sciences, Vol. 69, No. 4, Nov. 2019, 327-341.

[25] Martinazzo, A. P., Oliveira, F. da S. de, and Teodoro, C. E. de S. Antifungal activity of Cymbopogon citratus essential oil against Aspergillus flavus. Ciência e Natura, Vol. 41, No. 20 July 2019, 1-8. 
[26] Mirhendi, H., et al. A one enzyme PCR RFLP assay for identification of six medically important Candida species. Nihon Ishinkin Gakkai Zasshi, Vol. 47, No.3, Feb. 2006, 225-229.

[27] Pereira, F. D. O., et al. Antifungal activity of geraniol and citronellol, two monoterpenes alcohols, against Trichophyton rubrum involves inhibition of ergosterol biosynthesis. Pharmaceutical biology, Vol. 53, No. 2, Feb. 2015, 228-234.

[28] Ploetz, R. C., and Freeman, S. Foliar, floral and soilborne diseases. In: Litz, R. E. (ed.) The mango: botany, production and uses. 2nd ed. Wallingford: CABI, 2009, 231-302.

[29] Puškárová, A., et al. The antibacterial and antifungal activity of six essential oils and their cyto/genotoxicity to human HEL 12469 cells. Scientific reports, Vol, 7, No. 1, Aug. 2017, 1-11.

[30] Rios, J. L.. Essential oils: What they are and how the terms are used and defined. In: Preedy, V. R. (ed) Essential oils in food preservation, flavor and Safety. Academic Press, 2016, 3-10.

[31] Santos, G. R. D., et al., Effect of essential oils of medicinal plants on leaf blotch in Tanzania grass. Revista Ciência Agronômica, Vol. 44, No. 3, July/ Sept. 2013, 587-593.

[32] Santos, S. F. dos, et al. Post-harvest losses of fruits and vegetables in supply centers in Salvador, Brazil: Analysis of determinants, volumes and reduction strategies. Waste Management, Vol. 101, No. s/n, Jan. 2020, 161-170.

[33] Saaiman, W. C. Biology and control of Nattrassia mangiferae. In: Lavi, U. et al. (eds.). Proceedings of the 5th International Mango Symposium. Israel: Leuven International Society for Horticultural Science, 1997, 558565.

[34] Sarkhosh, A., et al. In vitro evaluation of eight plant essential oils for controlling Colletotrichum, Botryosphaeria, Fusarium and Phytophthora fruit rots of avocado, mango and papaya. Plant Protection Science, Vol. 54, No. 3, May. 2018, 153-162.

[35] Statsoft, Inc. STATISTICA (data analysis software system), version 7, 2004.

[36] Tavares, S. C. C. de H. Epidemiologia e manejo integrado de Botryodiplodia theobromae - Situação atual no Brasil e no mundo. Fitopatologia Brasileira, Vol. 27, No. s/n, 2002, 46-52.

[37] Terao, D., Nechet, K. de L., and Halfeld-Vieira, B. de A. Competitive and colony layer formation ability as key mechanisms by yeasts for the control Botryosphaeria dothidea fruit rot of mango. Tropical Plant Pathology, Vol. 42, No. 6, Dec. 2017, 451-457

[38] Terao, D., Batista, D. C., e Barbosa, M. A. G. Doenças em pós-colheita de manga. Circular técnica, Vol. s/v, No. 105, Dez. 2013, 1-8.

[39] Vyshali, P., Saraswathi, K.J T., and Mallavarapu, G. R. Chemical composition of the essential oils of Cymbopogon citratus (DC.) stapf grown in three locations in South India. Journal of Essential Oil Bearing Plants, Vol. 18, No. 1, Apr. 2015, 230-235.

[40] Zhang, Z., et al. Antifungal activity of monoterpenes against Botryosphaeria dothidea. Natural Product Communications, Vol. 13, No. 12, Nov. 2018, 1721-1724. 